\title{
Correction to: Unfolding identity of financial institutions in bitcoin blockchain by weekly pattern of network flows
}

\author{
Rubaiyat Islam $^{1}$ (D) $\cdot$ Yoshi Fujiwara $^{1} \cdot$ Shinya Kawata ${ }^{1,3} \cdot$ Hiwon Yoon $^{2}$
}

Published online: 12 June 2021

(c) The Author(s) 2021

\section{Correction to: Evolutionary and Institutional Economics Review (2021) 18:131-157 \\ https://doi.org/10.1007/s40844-020-00184-z}

The article "Unfolding identity of financial institutions in bitcoin blockchain by weekly pattern of network flows", written by Rubaiyat Islam, Yoshi Fujiwara, Shinya Kawata and Hiwon Yoon, was originally published Online First without Open Access. After publication in volume 18, issue 1, page 131-157 the author decided to opt for Open Choice and to make the article an Open Access publication. Therefore, the copyright of the article has been changed to (C) The Author(s) 2021 and the article is forthwith distributed under the terms of the Creative Commons AttributionNonCommercial 4.0 International License, which permits any non-commercial use, sharing, adaptation, distribution and reproduction in any medium or format, as long as you give appropriate credit to the original author(s) and the source, provide a link to the Creative Commons licence, and indicate if changes were made. The images or other third party material in this article are included in the article's Creative Commons licence, unless indicated otherwise in a credit line to the material. If material is not included in the article's Creative Commons licence and your intended use is not permitted by statutory regulation or exceeds the permitted use, you will need to obtain permission directly from the copyright holder To view a copy of this licence, visit http://creativecommons.org/licenses/by-nc/4.0/.

The original article has been corrected.

The original article can be found online at https://doi.org/10.1007/s40844-020-00184-z.

Rubaiyat Islam

rubaiyat.islam1982@gmail.com

1 Graduate School of Simulation Studies, University of Hyogo, Kobe 650-0047, Japan

2 CMD Laboratory Inc., Tokyo 151-0051, Japan

3 SCIO THINK LLC., Tokyo 171-0022, Japan 
Open Access This article is licensed under a Creative Commons Attribution-NonCommercial 4.0 International License, which permits any non-commercial use, sharing, adaptation, distribution and reproduction in any medium or format, as long as you give appropriate credit to the original author(s) and the source, provide a link to the Creative Commons licence, and indicate if changes were made. The images or other third party material in this article are included in the article's Creative Commons licence, unless indicated otherwise in a credit line to the material. If material is not included in the article's Creative Commons licence and your intended use is not permitted by statutory regulation or exceeds the permitted use, you will need to obtain permission directly from the copyright holder. To view a copy of this licence, visit http://creativecommons.org/licenses/by-nc/4.0/.

Publisher's Note Springer Nature remains neutral with regard to jurisdictional claims in published maps and institutional affiliations. 